\title{
Effects of ocean acidification on growth, organic tissue and protein profile of the Mediterranean bryozoan Myriapora truncata
}

\author{
Chiara Lombardi ${ }^{1, *}$, Silvia Cocito ${ }^{1}$, Maria Cristina Gambi ${ }^{2}$, Barbara Cisterna ${ }^{3}$, \\ Francine Flach ${ }^{3}$, Paul D. Taylor ${ }^{4}$, Kim Keltie $^{5}$, Andrew Freer ${ }^{5}$, Maggie Cusack ${ }^{6}$ \\ ${ }^{1}$ ENEA Marine Environment Research Centre, PO Box 224, 19100 La Spezia, Italy \\ ${ }^{2}$ Laboratory of Functional and Evolutionary Ecology, Stazione Zoologica Anton Dohrn, 80121 Naples, Italy \\ ${ }^{3}$ Laboratory of Cellular Biology and Neurobiology, Department of Animal Biology, University of Pavia, 27100 Pavia, Italy \\ ${ }^{4}$ Department of Palaeontology, Natural History Museum, Cromwell Road, London SW7 5BD, UK \\ ${ }^{5}$ Glasgow Biomedical Research Centre, University of Glasgow, Glasgow G12 8TA, UK \\ ${ }^{6}$ School of Geographical \& Earth Sciences, University of Glasgow, Glasgow G12 8QQ, UK
}

\begin{abstract}
The possible effects of ocean acidification on growth, organic tissue and protein profile in the bryozoan Myriapora truncata (Pallas, 1766) were studied in samples transplanted along a gradient of different $\mathrm{pH}$ conditions in an area of natural volcanic $\mathrm{CO}_{2}$ vents at Ischia Island (Tyrrhenian Sea, Italy). Living colonies from normal (mean $\mathrm{pH} 8.10$ ), intermediate ( $\mathrm{pH} 7.83$ ) and low (pH 7.32) pH sites were investigated after intervals of 34,57 and $87 \mathrm{~d}$ of exposure. M. truncata formed new and complete zooids at the normal site, whereas at the intermediate and low $\mathrm{pH}$ sites, neither partial nor complete zooids were produced. After $34 \mathrm{~d}$ at intermediate and low $\mathrm{pH}$ conditions, the organic cuticle which envelops the skeleton increased in thickness when compared to normal colonies, suggesting a protective role against dissolution of the high-Mg calcite skeleton. Significant changes in the protein profile and expression displayed by samples from intermediate and low $\mathrm{pH}$ conditions suggest that $M$. truncata makes an initial attempt to overcome the decrease in $\mathrm{pH}$ by up-regulating protein production but eventually, especially in the lowest $\mathrm{pH}$ condition, exhausts biochemical energy to maintain this rate of protein production, leading to eventual death.
\end{abstract}

KEY WORDS: Ocean acidification · Bryozoa $\cdot$ Organic tissues $\cdot$ Protein $\cdot$ Growth $\cdot$ Mediterranean Sea $\cdot$ Myriapora truncata

\section{INTRODUCTION}

Anthropogenic carbon dioxide $\left(\mathrm{CO}_{2}\right)$ has already caused ocean $\mathrm{pH}$ to decrease by an average of 0.1 units since pre-industrial time (Raven et al. 2005). By 2100 , it is projected to fall by 0.3 to $0.5 \mathrm{pH}$ units (Caldeira \& Wickett 2005, Orr et al. 2005). The oceans store up to a quarter of the atmospheric $\mathrm{CO}_{2}$ produced by human activities. When $\mathrm{CO}_{2}$ dissolves into the oceans, it forms carbonic acid, increasing ocean acidity and shifting the chemical equilibrium towards $\mathrm{CO}_{2}$ and bicarbonate ions, with a decrease in carbonate ion concentration. This decrease, coupled with an increase in $\mathrm{CO}_{2}$ gas dissolved in the oceans, reduces the saturation state $(\Omega)$ of seawater with respect to calcium carbonate minerals. Because of the positive correlation between $\Omega$ and the rate of formation of carbonates, the distribution and dissolution of carbonates are both sensitive to oceanic $\Omega$ and $\mathrm{pH}$. Variations in this saturation state not only alter the geochemical balance of the oceans but directly affect marine calcifying organisms with subsequent 
effects for global ecosystems (Pörtner et al. 2005, Kleypas et al. 2006).

Biominerals are composed of inorganic minerals and organic macromolecules such as proteins, proteoglycans, lipids and polysaccharides. These macromolecules are fundamental in controlling the intricate detail of shell formation, determining nucleation, stabilisation and mineral polymorph formation (Marin et al. 1996, Cölfen \& Antonietti 2005, Fu et al. 2005, Nudelman et al. 2007, Cusack \& Freer 2008). Organic macromolecules also play an active role in the formation of organic tissues that, in most calcifying organisms, separate shell or skeletons from ambient seawater (Ries et al. 2009). Crustaceans, for example, enclose their carapace within a thick epicuticle (Roer \& Dillaman 1984); molluscs and brachiopods cover their shells with a periostracum (Marin et al. 1996, Nudelman et al. 2007, Cusack \& Freer 2008, Evans 2008); corals nucleate aragonite beneath several layers of epithelial tissue (Gattuso et al. 1999, Perrin 2003); and the bryozoan skeleton is enveloped by an organic cuticle (Lutaud 1961, Hunt 1972, TavenerSmith \& Williams 1972).

Among biomineralisers, bryozoans are a key component of marine ecosystems, secreting calcareous skeletons that provide habitat for other organisms while playing an important role in the carbon cycle (Cocito 2004, Smith 2009). These colonial organisms are composed of modular units (i.e. zooids) which include inorganic (i.e. skeleton) and organic components (i.e. cuticle and polypide; McKinney \& Jackson 1989) strictly connected to each other in both origin and function. The bryozoan skeleton is secreted beneath an organic cuticle that evaginates from the budding site of the mother zooid (Lutaud 1961). The cuticle is deposited by epithelial cells that exude an organic coating that acts as a seeding surface for the nucleation of the first crystallites of the mineral skeleton. Calcification proceeds from proximal to distal end and occurs as soon as the cuticle is deposited, such that the proximal portion calcifies before the distal parts of the zooid walls are delimited by the expanding cuticle (Lutaud 1961, Gordon 1971). As organic components, bryozoan modular units also comprise the polypide, a partially extendable unit that includes the nervous system, digestive tract, some specialised muscles and the feeding apparatus, bearing many ciliated tentacles that are extended during feeding or collapsed and withdrawn into the colony interior (McKinney \& Jackson 1989).

Bryozoans are bioindicator organisms that are able to adopt appropriate morphological and functional responses to environmental changes (McKinney \& Jack- son 1989, O'Dea \& Okamura 1999, Jackson \& Herrera Cubilla 2000, Lombardi et al. 2006, 2011a, Hageman et al. 2009). Bryozoan skeletons are potentially vulnerable to climate changes such as increased water temperatures (Lombardi et al. 2008, Knowles et al. 2010) and decreased $\mathrm{pH}$ due to ocean acidification (Smith 2009, Rodolfo-Metalpa et al. 2010, Lombardi et al. 2011b). The first in situ transplantation experiments, performed by Rodolfo-Metalpa et al. (2010) and Lombardi et al. (2011b) on the Mediterranean bryozoan Myriapora truncata (Pallas, 1766) at a volcanic $\mathrm{CO}_{2}$ vent in Ischia, Italy (see Hall-Spencer et al. 2008 for site description), showed changes in the rates of calcification and dissolution as well as changes in the structure and composition of the skeleton due to decreased $\mathrm{pH}$. These studies also suggested the possibility that the cuticle played a role in protecting against corrosion by decreased $\mathrm{pH}$ seawater.

To extend our knowledge in terms of how the organic constituents involved in bryozoan biomineralisation react to decreased $\mathrm{pH}$ conditions, a new in situ transplantation experiment was set up using the bryozoan Myriapora truncata. This cheilostome bryozoan produces a biomineralised skeleton of high-Mg calcite beneath the envelopment comprising secretory epithelium, coelom, outer epithelium and outermost organic cuticle. Living colonies were deployed into cages at various distances from $\mathrm{CO}_{2}$ vents, along a gradient of different $\mathrm{pH}$ conditions, for intervals of 34,57 and $87 \mathrm{~d}$. The aim was to analyse effects of acidification on growth, organic tissue and protein composition.

\section{MATERIALS AND METHODS}

\section{Target species}

Myriapora truncata is a widespread bryozoan found in a variety of habitats, from shallow subtidal sheltered sites to circalittoral rocky environments, in the Mediterranean and along the western Atlantic coasts of southern Spain and Morocco (Canu \& Bassler 1925, López de la Cuadra \& García-Gómez 1994). It grows in erect tree-like colonies with a robust skeleton made by branches composed of radiating, undifferentiated autozooids (feeding units) arranged around an axial bundle of kenozooids, formed for structural reasons (Berning 2007). The frontal wall, or shield, of $M$. truncata is secreted beneath a covering of coelom and an outer envelope of organic cuticle. The main body of the animal, the polypide, is located within the box-shaped skeletal 
walls of the zooid and protrudes through the primary orifice to feed. The expanded polypide has an inverted cone-shaped crown of tentacles (i.e. lophophore) bearing cilia which create a current of water that propels food particles towards the mouth, which lies at the base of the lophophore. Each tentacle tip ends with a tuft of rigid cilia, which are also present at the abfrontal and the latero-frontal sides of the tentacle, and which have been observed to have sensory functions in several bryozoan species (Lutaud 1973, 1993, Gordon 1974, Winston 1978). Although some information exists about the morphology of the larva, of the first formed zooid (ancestrula; Ferretti et al. 2007) and net calcification rate (Rodolfo-Metalpa et al. 2010), the life cycle, zooid growth rate and diet of M. truncata are still unknown.

\section{Fieldwork}

Fieldwork was carried out from 7 June to 8 September 2009 off the southern coast of Ischia Island, Italy $\left(40^{\circ} 41.31^{\prime} \mathrm{N}, 13^{\circ} 53.36^{\prime} \mathrm{E}\right)$ in an area of natural volcanic $\mathrm{CO}_{2}$ vents which cause a gradient of water acidification. Descriptions of the vent area and its main habitat features are reported in previous studies (Hall-Spencer et al. 2008, Cigliano et al. 2010). Colonies of Myriapora truncata were collected from a rocky bank (Secca delle Formiche di Vivara) $2 \mathrm{~km}$ north, far from the volcanic area, and transported to the laboratory where they were maintained in $20 \mathrm{l}$ aquaria with a turnover rate of seawater of $50 \% \mathrm{~h}^{-1}$. Only live colonies were selected for the experiment. Seventy-two colony fragments (up to 3 branches each) were attached to tagged plastic plates using epoxy glue (HoldFast ${ }^{\circledR}$; Rodolfo-Metalpa et al. 2010), mounted on PVC plates and distributed in 6 cages $(30 \times 50 \mathrm{~cm})$ with 12 fragments cage $^{-1}$. The cages were transplanted to the south side of Castello Aragonese $\left(40^{\circ} 43.84^{\prime} \mathrm{N}, 13^{\circ} 57.08^{\prime} \mathrm{E}\right)$ at 3 to $4 \mathrm{~m}$ depth along a $200 \mathrm{~m}$ transect at 3 sites (2 cages site ${ }^{-1}$, $2 \mathrm{~m}$ apart) where different mean $\mathrm{pH}$ conditions (normal, intermediate and low) due to $\mathrm{CO}_{2}$ vents have been documented in previous studies (Hall-Spencer et al. 2008, Cigliano et al. 2010, Rodolfo-Metalpa et al. 2010). Each cage was fixed to a $30 \mathrm{~kg}$ concrete block to prevent movement of the cage and colony breakage. Due to the limited spatial extension of the vent area (especially in the low $\mathrm{pH}$ zone), it was not possible to place more than 2 cages site ${ }^{-1}$. Eight fragments were collected from each site (4 from each cage) after 34, 57 and $87 \mathrm{~d}$ of exposure: 4 fragments for histological analyses and 4 for protein analyses.
Seawater temperature data were obtained using 3 Hobo Onset loggers fixed to concrete blocks at each site, collecting data at 15 min intervals. For $\mathrm{pH}$ measurements, water samples were collected in $250 \mathrm{ml}$ polyethylene jars at $1 \mathrm{~m}$ depth between 10:30 and 12:00 h. Four replicated seawater samples were collected per site on each sampling date (16 dates). Jars were subsequently transported to the laboratory, using an isolated thermal box in order to maintain in situ temperature conditions. In the laboratory, $\mathrm{pH}$ and temperature were measured $(\mathrm{pH} 300$ Hanna Instrument with a resolution of 0.01 and associated thermistor) within $2 \mathrm{~h}$ of collection. The $\mathrm{pH}$ meter was calibrated using SIGMA standard reference buffers for $\mathrm{pH} 4.00,7.00$ and 10.00 at $25^{\circ} \mathrm{C}$. All laboratory $\mathrm{pH}$ data were then adjusted using the equation of Gieskes (1969) $\left(\mathrm{pH}=\mathrm{pH}_{1}+0.0114\left[\mathrm{t}_{1}-\mathrm{t}_{\mathrm{m}}\right]\right)$, where $\mathrm{pH}_{1}$ is the $\mathrm{pH}$ measured in the lab by the instrument, $t_{1}$ is the measuring temperature and $t_{m}$ is the in situ temperature). Differences in temperature and $\mathrm{pH}$ conditions among sites and sampling periods were tested using 2-way analysis of variance (ANOVA). Prior to analysis, Levene's test was employed to assess the equality of variances across the samples. When variances were heterogeneous, data transformations (square root, logarithmic, arcsine) were applied, and in case of persistent heterogeneity, the more stringent criterion of $\alpha<0.01$ was used to reject the null hypothesis ( $\mathrm{pH}$ values among sites and periods were invariant). When appropriate, a Student-Newman-Keuls (SNK) test was applied for multiple comparisons of the means.

\section{Zooid growth rate}

Prior to histological and protein analyses, 1 branch for each fragment (4 fragments per duplicate cage from each of the 3 sites collected at intervals of 34, 57 and 87 d) was used for counting the newly formed zooids at the growing tips of Myriapora truncata. Fragments, individually tagged with plastic plates, were photographed before being transplanted and prior to fixation for histological and protein analyses. Two photographs were taken for each branch of $M$. truncata, one for each side of the growing tip, always maintaining the sample perpendicular to the camera. A binocular microscope (Leica Z16 APO, objective $1 \times$, oculars $10 \times$, magnification from 14.2 to $230 \times$, field diameter from 14.8 to $0.9 \mathrm{~mm}$ ) with a digital camera (Leica DFC 300 FX) connected to a computer with dedicated software (Leica LAS $^{\circledR}$ ) were used for the analysis. For each branch, subsequent images were 
compared and the newly formed zooids were marked manually using CPCe software (Kohler \& Gill 2006). Only complete zooids were counted. The numbers of newly formed zooids counted on each side of the growing tip were summed up, then averaged for each sample for the 2 replicate cages from the 3 sites at each sampling time. After verification of the homogeneity of variances (Levene's test, p > 0.05), 2-way ANOVA was used to compare data on newly formed zooids. When ANOVA revealed significant differences ( $p<0.05)$, an SNK test was used for pairwise comparisons.

\section{Cuticle and polypide analysis}

Cuticle was separated from the skeleton of the zooids using forceps under a binocular microscope. Three sections of cuticle from the 2 replicate cages exposed at the 3 sites for the 3 times were analysed. Cuticles were fixed with a solution of $2.5 \%$ glutaraldehyde and $0.25 \%$ paraformaldehyde (PFA) in phosphate-buffered saline (PBS) for $2 \mathrm{~h}$, rinsed in $\mathrm{PBS}$ and fixed in $2 \% \mathrm{OsO}_{4}$ for $30 \mathrm{~min}$. The specimens were dehydrated in acetone at room temperature and embedded in EPON resin. Cuticle sections were analysed using scanning electron microscopy (SEM; EVO LS 15, Zeiss) at 1000× magnification, and cuticle thickness $(\mu \mathrm{m})$ was measured on SEM pictures with Image $\mathrm{J}^{\circledR}$ at 3 points for each section. Four-way ANOVA (site, period, cage, points of cuticle section) was used to test significant differences in cuticle thickness. Prior to analysis, Levene's test was employed to test the homogeneity of variances across the samples. When ANOVA indicated significant differences, an SNK test was applied for multiple comparisons of the means.

Polypides were extracted from the skeleton using a dissecting needle and forceps under a binocular microscope and then fixed with $4 \%$ PFA in PBS $(\mathrm{pH}$ 7.2) at room temperature for $2 \mathrm{~h}$ and then rinsed in PBS. The specimens were placed in $0.5 \mathrm{M} \mathrm{NH}_{4} \mathrm{Cl}$ solution in PBS for $15 \mathrm{~min}$ to block free aldehyde groups, then dehydrated in ethanol at room temperature and embedded in LRWhite resin. The ultrathin sections of the polypides, placed on nickel grids covered with Formvar-carbon film, were stained with the EDTA regressive technique (Bernhard 1969). This technique is preferred for the detection of ribonucleoprotein-containing nuclear components, which are involved in the maturation of RNA. The specimens were observed with a Zeiss 900 EM operating at $80 \mathrm{kV}$.

\section{Protein analysis}

Four fragments per time period were rinsed extensively with deionised water and dried overnight in an oven at $37^{\circ} \mathrm{C}$. Then $1 \mathrm{~g}$ of each sample was crushed to a fine powder and dissolved with $23 \mathrm{ml}$ of an aqueous solution of EDTA (0.2 M, pH 8.0) and $0.1 \mathrm{ml}$ of dithiothreatol (DTT). Protein concentration was determined using a Nanodrop spectrophotometer (Thermo Scientific). Importantly, all bryozoan protein samples used throughout the analysis were adjusted to be approximately the same concentration. This ensured that, as far as possible, equal amounts of protein from each sample were loaded onto the gel. Due to the paucity of proteins extracted from the soluble matrix of each sample, silver staining with SDSPAGE was employed. The EDTA-solubilised samples were concentrated to approximately one-fifth of their original volume using Vivaspin (Sartorius) concentrator tubes with a $10 \mathrm{kDa}$ molecular weight cut-off. This cut-off was a compromise between the need to reduce sample volume and increase protein concentration and speed of the process, since EDTA samples are notoriously difficult to pass through a membrane. Hence, proteins with a molecular weight lower than approximately $10 \mathrm{kDa}$ are not visualised. Silver staining is approximately 50 times more sensitive than traditional Coomassie visualisation, detecting proteins at the 0.3 to $1.0 \mathrm{ng}$ level (Switzer et al. 1979). Since protein content of biomineralised material is between 1 and 5\% total weight (Noguchi et al. 2007), tending to the lower end for bryozoans, according to our methodology, Coomassie staining shows no observable protein bands. The silver staining protocol was adapted according to instructions enclosed in the SilverXpress staining kit (Invitrogen). Additional care to exclude light during the staining process produced significantly better results. The samples were separated alongside protein standards of known molecular weight: myosin (188 kDa), phosphorylase (98 kDa), bovine serum albumin (62 kDa), glutamic dehydrogenase (49 kDa), alcohol dehydrogenase (38 kDa), carbonic anhydrase (28 kDa), myoglobin red $(17 \mathrm{kDa})$, lysozyme $(14 \mathrm{kDa})$ and aprotinin (6 kDa).

\section{RESULTS}

\section{pH and temperature data}

Throughout the study period ( 7 June to 8 September 2009), pH values at the normal site were the 
highest recorded and relatively constant with a mean $\pm \mathrm{SD}$ value of $8.10 \pm 0.07$ (Table 1 ). The intermediate $\mathrm{pH}$ site was characterised by a mean $\mathrm{pH}$ value of $7.83 \pm 0.41$, while the lowest values were observed at the low $\mathrm{pH}$ site $(7.32 \pm 0.47$; Table 1$)$. Two-way ANOVA revealed significant differences among sites $(F=56.60, \mathrm{p}<0.01$; SNK test: normal $>$ intermediate $>$ low).

During the study period, the mean seawater temperature was $26.2 \pm 0.09^{\circ} \mathrm{C}$ at the normal site, $26.2 \pm$ $1.2^{\circ} \mathrm{C}$ at the intermediate $\mathrm{pH}$ site, and $26.5 \pm 1.2^{\circ} \mathrm{C}$ at the low $\mathrm{pH}$ site (Table 1). Differences among sites were not found, although significant differences were found among periods (2-way ANOVA, $F=4.02$, $\mathrm{p}<0.05$ ) with highest values after 57 (early August) and $87 \mathrm{~d}$ (early September; SNK, $34<57=87$ ). The

Table 1. Mean $( \pm \mathrm{SD}) \mathrm{pH}$ and seawater temperature measured at the normal, intermediate and low $\mathrm{pH}$ sites during 34, 57 and 87 d periods starting 7 June 2009

\begin{tabular}{|lccc|}
\hline Site & Period & $\mathrm{pH}$ & Temperature $\left({ }^{\circ} \mathrm{C}\right)$ \\
\hline Normal pH & 34 & $8.09 \pm 0.08$ & $25.1 \pm 0.8$ \\
& 57 & $8.09 \pm 0.08$ & $26.5 \pm 0.8$ \\
Intermediate $\mathrm{pH}$ & 37 & $8.10 \pm 0.07$ & $26.2 \pm 0.9$ \\
& 57 & $7.63 \pm 0.42$ & $25.2 \pm 0.9$ \\
& 87 & $7.83 \pm 0.45$ & $25.6 \pm 0.9$ \\
Low pH & 34 & $7.28 \pm 0.48$ & $25.2 \pm 1.2$ \\
& 57 & $7.29 \pm 0.47$ & $25.8 \pm 0.9$ \\
& 87 & $7.32 \pm 0.47$ & $26.5 \pm 1.2$ \\
\hline
\end{tabular}

seawater temperature trend (daily average) recorded at the low pH site (Fig. 1) is representative of temperature trends recorded at the other 2 sites for the study period.

\section{Myriapora truncata growth}

Myriapora truncata formed new and complete zooids only at the normal pH site, whereas at the other sites, neither partial nor complete zooids were produced. At normal $\mathrm{pH}$, the mean number of zooids progressively increased at the growing tip of samples (cages averaged) from $0.6 \pm 0.5$ after $34 \mathrm{~d}$, to $2.1 \pm 1.0$ after $57 \mathrm{~d}$, up to $3.1 \pm 0.8$ at the end of the experiment (Fig. 2). After $87 \mathrm{~d}$, the mean number of new zooids did not significantly vary between cages, but was significantly different (2-way ANOVA, $F=15.11$, p < 0.001 ) from the mean number of new zooids formed after both 34 and $57 \mathrm{~d}(\mathrm{SNK}, \mathrm{p}<0.01)$.

\section{Cuticle and polypide histology}

Histological investigations revealed differences in cuticle thickness and texture between samples exposed along the $\mathrm{pH}$ gradient for 34,57 and $87 \mathrm{~d}$. At the normal $\mathrm{pH}$ site, cuticle thickness remained constant through time $(3.70 \pm 0.34 \mu \mathrm{m})$, whereas samples exposed to intermediate and low $\mathrm{pH}$ initially had thicker cuticles after $34 \mathrm{~d}$ of exposure (intermediate:

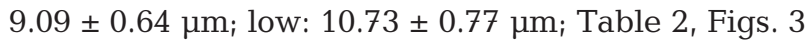

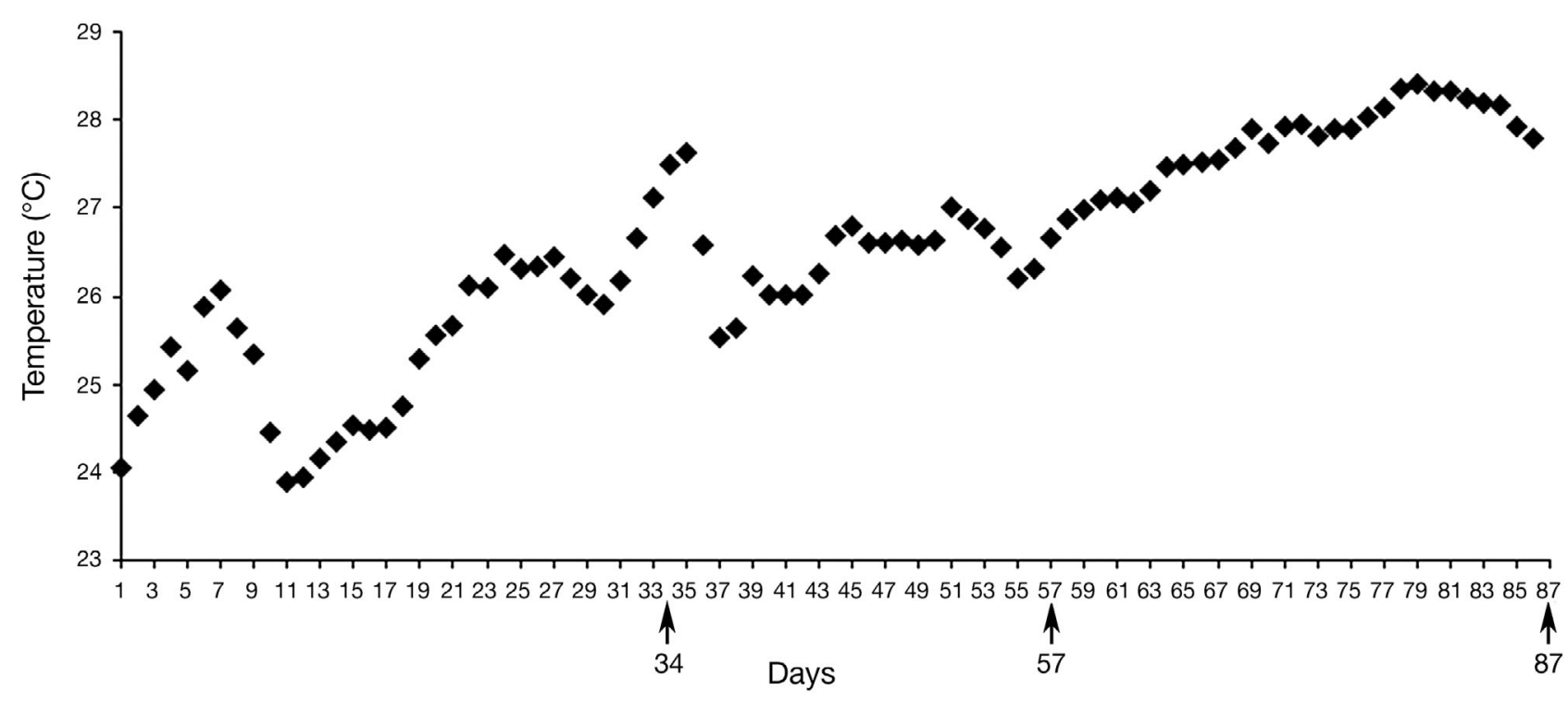

Fig. 1. Seawater temperature trend (daily average) recorded at the low $\mathrm{pH}$ site throughout the study period (starting 7 June 2009). Arrows indicate the end of each of the 3 measurement periods listed in Table 1 


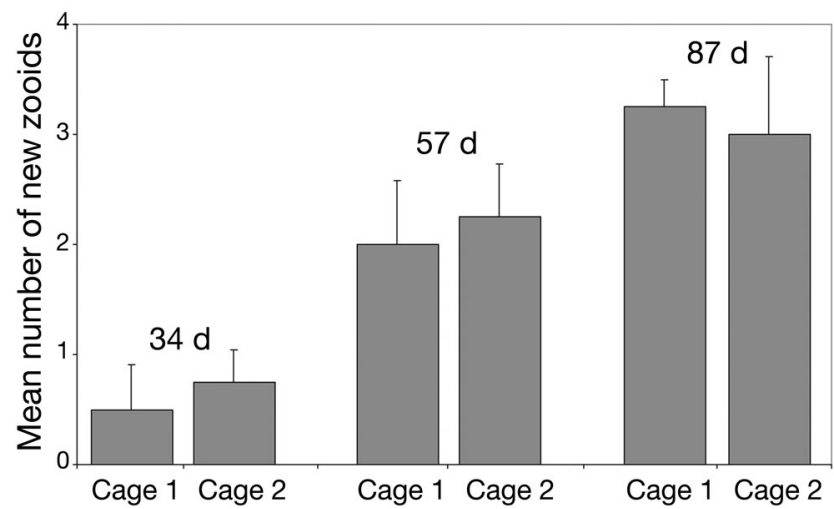

Fig. 2. Myriapora truncata. Mean ( \pm SE) number of new zooids formed in samples deployed in the duplicate cages at the normal $\mathrm{pH}$ site after increasing times of exposure $(34,57$ and $87 \mathrm{~d}$ from 7 June 2009) vealed regularly oriented thickened fibres, organised in a more dense structure than those at the normal $\mathrm{pH}$ site (Fig. 5).

Comparing ultrathin sections of the lophophore tentacles of samples from all 3 sites, there were no observable differences in tissue organisation after 34, 57 and $87 \mathrm{~d}$ of exposure, whereas differences related to cellular functioning (i.e. heterochromatin densely clumped at the nuclear margins) were clearly detected in samples exposed to low $\mathrm{pH}$ conditions even after $34 \mathrm{~d}$ of exposure. At this site, the tentacle of the lophophore had a fibrous envelope covering the tentacle tip (Fig. 6a). The distal outer part of the tentacle was characterised by an extracellular matrix with a reticular composition and a line of cilia reaching the boundary of the tentacle (Fig. 6b), and the inner part

\& 4). However, after 57 and $87 \mathrm{~d}$, samples from the intermediate $\mathrm{pH}$ site showed a progressive decrease in cuticle thickness $(57 \mathrm{~d}$ : $8.43 \pm 0.52 \mu \mathrm{m}$; $87 \mathrm{~d}: 5.95 \pm 0.43 \mu \mathrm{m})$. Samples from the low $\mathrm{pH}$ site showed a substantial decrease in cuticle thickness from 10.73 to $7.12 \mu \mathrm{m}$ between 34 and $57 \mathrm{~d}$, and thereafter, the values remained approximately constant (57 d: $7.12 \pm$ $0.59 \mu \mathrm{m}_{\text {; }} 87 \mathrm{~d}$ : $7.63 \pm 0.67 \mu \mathrm{m}$; Figs. 3 \& 4). Four-way ANOVA revealed significant differences $(F=1004.36, \mathrm{p}<0.01)$ among sites during the first period of exposure $\left(34 d_{i}\right.$ SNK: normal < intermediate < low). Differences in cuticle appearance were also observed by analysing ultrathin longitudinal sections of samples exposed at the normal and low $\mathrm{pH}$ sites for $34 \mathrm{~d}$. After $34 \mathrm{~d}$, cuticle texture from the low $\mathrm{pH}$ site re-

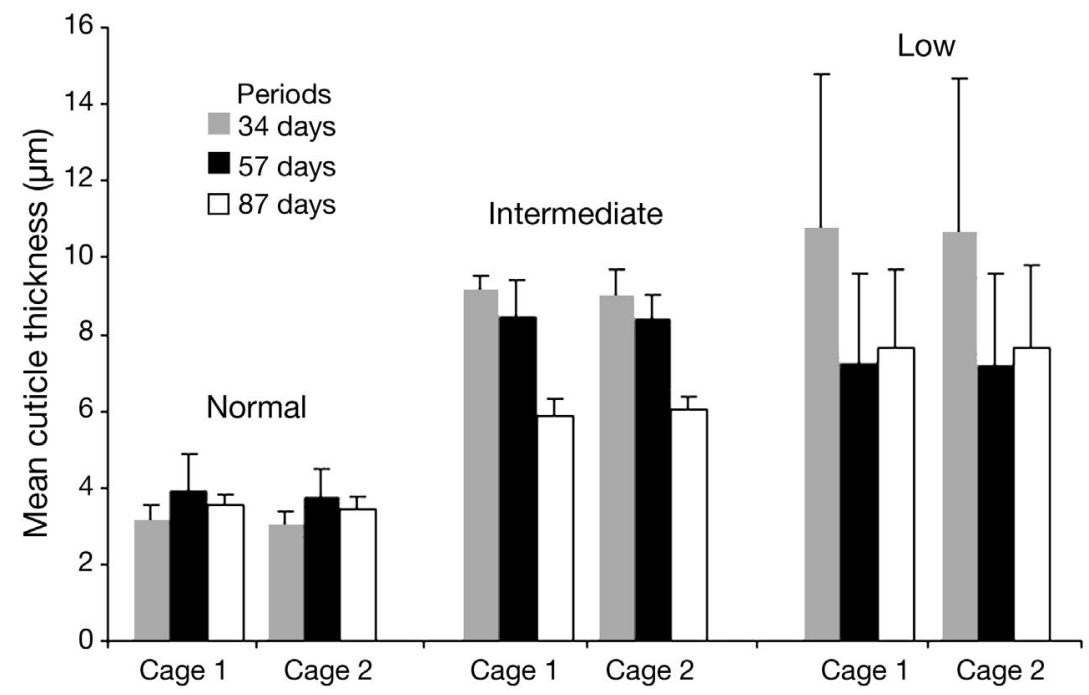

Fig. 3. Myriapora truncata. Mean ( \pm SD) cuticle thickness $(\mu \mathrm{m})$ of zooids in samples deployed in duplicate cages at the normal, intermediate and low $\mathrm{pH}$ sites after increasing times of exposure $(34,57$ and 87 d) from 7 June 2009

Table 2. Myriapora truncata. Mean $( \pm \mathrm{SD})$ cuticle thickness of zooids $(\mu \mathrm{m})$ measured on samples $(\mathrm{n}=3)$ from duplicate cages (Cages 1 and 2) exposed to normal, intermediate and low pH conditions for 34, 57 and 87 d from 7 June 2009

\begin{tabular}{|c|c|c|c|c|c|c|c|}
\hline \multirow[t]{2}{*}{ Site } & \multirow[t]{2}{*}{ Day } & \multicolumn{3}{|c|}{ - Cage 1} & \multicolumn{3}{|c|}{ - Cage 2} \\
\hline & & $\mathrm{a}$ & $\mathrm{b}$ & $\mathrm{C}$ & $\mathrm{a}$ & $\mathrm{b}$ & $\mathrm{C}$ \\
\hline \multirow[t]{3}{*}{ Normal pH } & 34 & $2.75 \pm 0.18$ & $3.33 \pm 0.13$ & $3.41 \pm 0.17$ & $2.70 \pm 0.38$ & $3.11 \pm 0.09$ & $3.37 \pm 0.20$ \\
\hline & 57 & $4.90 \pm 0.32$ & $3.90 \pm 0.71$ & $2.99 \pm 0.59$ & $4.44 \pm 0.42$ & $3.87 \pm 0.23$ & $2.94 \pm 0.60$ \\
\hline & 87 & $3.66 \pm 1.09$ & $3.23 \pm 0.21$ & $3.72 \pm 1.20$ & $3.19 \pm 0.64$ & $3.25 \pm 0.51$ & $3.82 \pm 0.93$ \\
\hline \multirow[t]{3}{*}{ Intermediate $\mathrm{pH}$} & 34 & $9.60 \pm 1.41$ & $8.90 \pm 0.36$ & $9.01 \pm 0.44$ & $9.77 \pm 0.95$ & $8.57 \pm 0.36$ & $8.66 \pm 0.36$ \\
\hline & 57 & $7.31 \pm 0.48$ & $8.89 \pm 0.31$ & $9.13 \pm 0.72$ & $7.81 \pm 0.86$ & $8.46 \pm 0.27$ & $8.99 \pm 0.16$ \\
\hline & 87 & $5.45 \pm 0.23$ & $6.35 \pm 0.23$ & $5.84 \pm 0.31$ & $5.59 \pm 0.47$ & $6.21 \pm 0.45$ & $6.23 \pm 0.41$ \\
\hline \multirow[t]{3}{*}{ Low $\mathrm{pH}$} & 34 & $10.88 \pm 0.66$ & $11.09 \pm 1.16$ & $10.39 \pm 0.53$ & $10.44 \pm 0.98$ & $10.92 \pm 0.89$ & $10.68 \pm 0.48$ \\
\hline & 57 & $7.73 \pm 0.56$ & $6.92 \pm 0.60$ & $7.05 \pm 0.78$ & $7.74 \pm 0.36$ & $6.71 \pm 0.64$ & $7.08 \pm 0.72$ \\
\hline & 87 & $8.44 \pm 1.02$ & $6.44 \pm 0.81$ & $8.00 \pm 0.77$ & $8.31 \pm 0.57$ & $6.61 \pm 0.59$ & $8.01 \pm 0.27$ \\
\hline
\end{tabular}



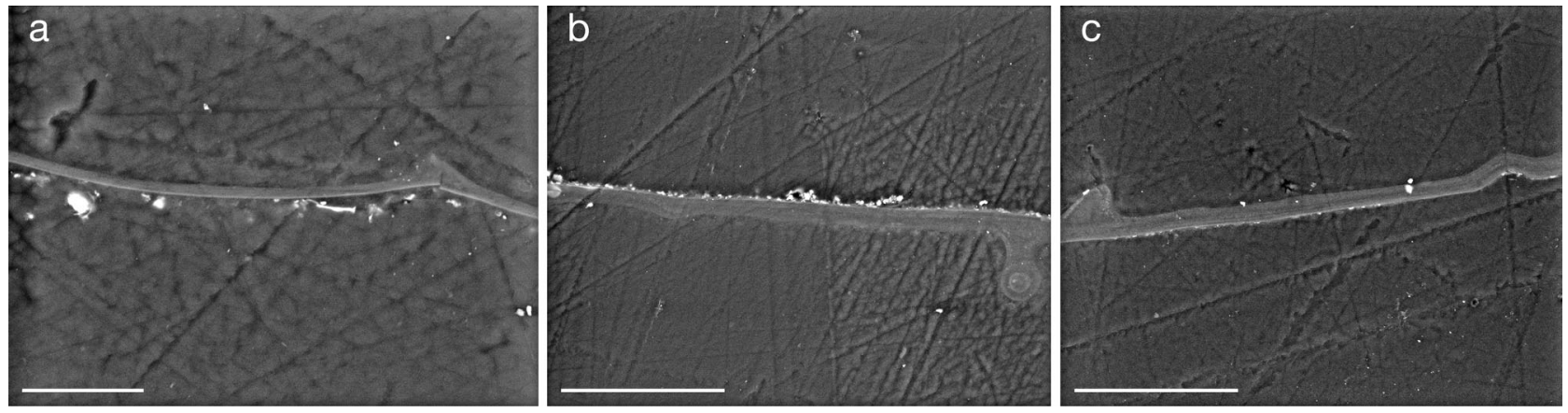

Fig. 4. Myriapora truncata. Scanning electron microscopy showing cuticle thickness in samples exposed for $34 \mathrm{~d}$ to (a) normal, (b) intermediate and (c) low pH conditions. Scale bars: (a) $=35 \mu \mathrm{m}$; (b, c) $=100 \mu \mathrm{m}$
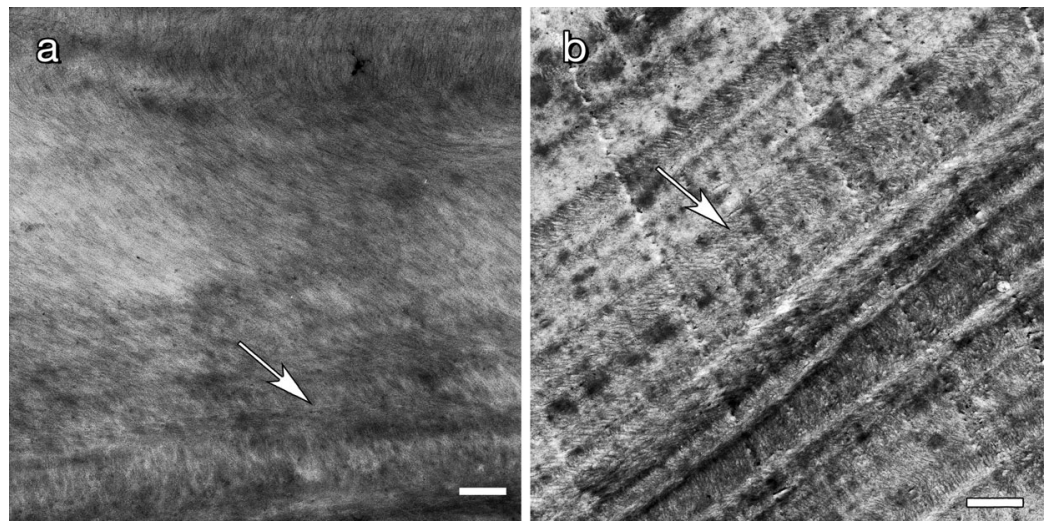

Fig. 5. Myriapora truncata. Details of the cuticle texture (arrows) of samples exposed for $34 \mathrm{~d}$ to (a) normal and (b) low $\mathrm{pH}$ conditions. Scale bars: (a) $=2 \mu \mathrm{m}$, (b) $=4 \mu \mathrm{m}$

showed cellular nuclei bearing cilia (Fig. 6c). The proximal outer part of the tentacle showed cellular nuclei and extracellular matrix, but tentacle cilia were not present (Fig. 6d). At both the distal and the proximal parts of the tentacle, cells showed a nucleus with a large amount of heterochromatin, particularly associated with the nuclear margin (arrows in Fig. $6 \mathrm{~b}-\mathrm{d})$, as was also evident using an EDTA regressive technique. Condensed heterochromatin in cell nuclei persisted throughout the entire duration of the study at this site.

Tentacle tissues from the intermediate $\mathrm{pH}$ site did not show irregularities either at the structural or the morphological level for the whole study period. Only a small amount of heterochromatin at the cellular nuclei was found in samples exposed for $87 \mathrm{~d}$. No differences were detected in the morphological and structural organisation of tissues from the normal site versus fresh samples collected at the time of histological analyses from a natural environment far from the volcanic vent area.

\section{Protein analysis}

Proteins in the molecular mass range of 10 to $100 \mathrm{kDa}$ were visualised (Fig. 7). Samples from the normal $\mathrm{pH}$ site showed the most distinctive bands, which remained almost identical over time $(34,57$ and $87 \mathrm{~d})$. In contrast, specimens grown under decreased $\mathrm{pH}$ conditions at the other 2 sites showed significant changes to the protein profile visualised by silver staining (Fig. 7). Samples from both of these sites showed an increase in production of protein during the initial $34 \mathrm{~d}$. However, after 57 and $87 \mathrm{~d}$, there was a marked decrease in protein production, with samples from the low $\mathrm{pH}$ site showing almost no protein (or very diffuse) bands, particularly after the longest exposure. Changes in specific protein expression were also evident: in samples from the intermediate $\mathrm{pH}$ site, there was an increase in concentration of the $76 \mathrm{kDa}$ protein (indicated with an asterisk in Fig. 7) from 34 to $57 \mathrm{~d}$ and then a decrease from 57 to $87 \mathrm{~d}$. This contrasted with the $95 \mathrm{kDa}$ protein (indicated by a triangle in Fig. 7), which was present in lower concentrations at 57 and $87 \mathrm{~d}$ compared to $34 \mathrm{~d}$.

\section{DISCUSSION}

The present study is the first to describe the effects of ocean acidification on growth, organic structure and protein expression in the bryozoan Myriapora truncata. This Mediterranean species is a feasible target organism for testing the effects of decreased $\mathrm{pH}$ conditions in the ocean: Rodolfo-Metalpa et al. (2010) 

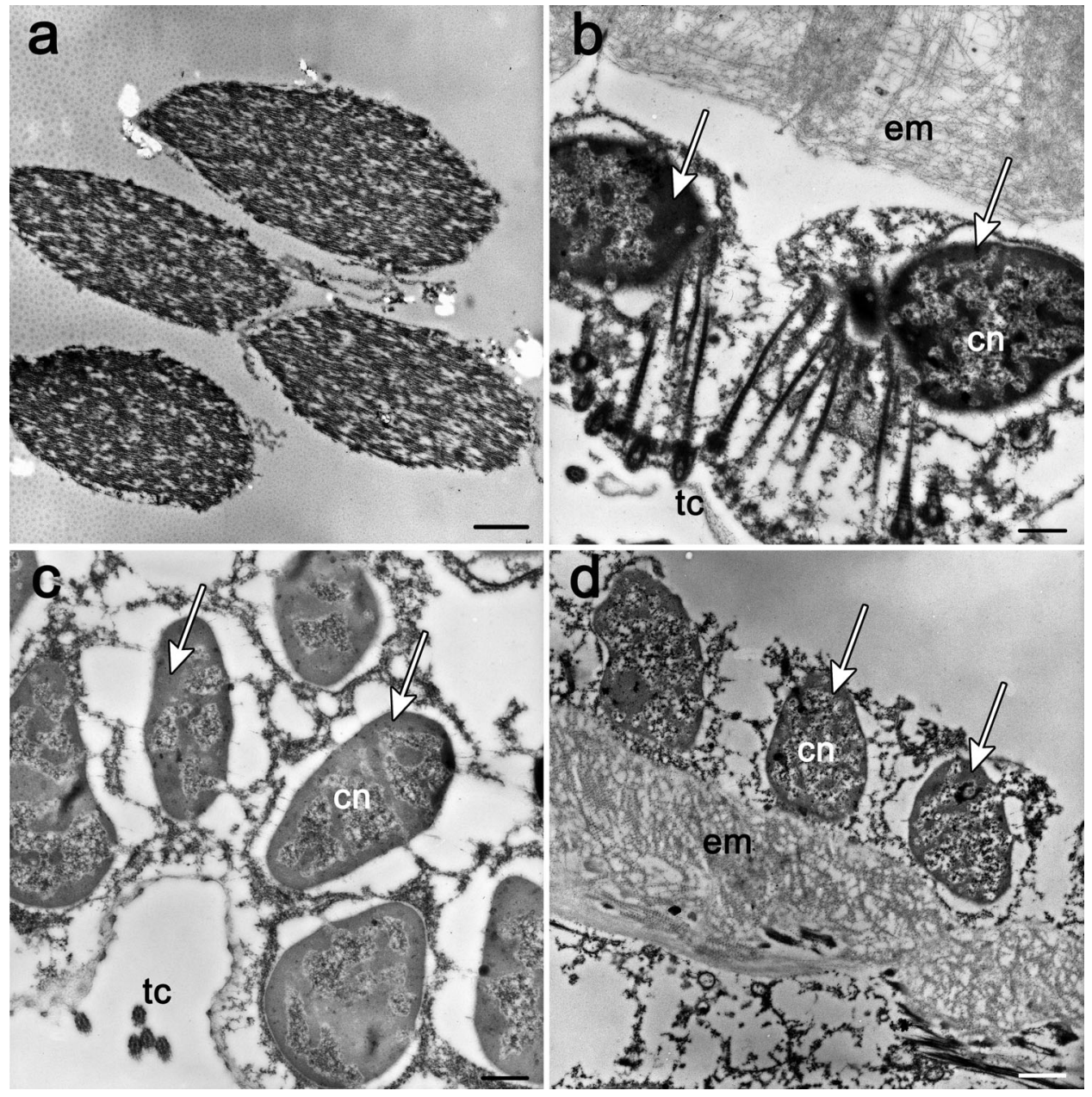

Fig. 6. Myriapora truncata. Transverse section of the lophophore tentacles from M. truncata exposed for $34 \mathrm{~d}$ to low pH. (a) Tentacle tips distally covered by a fibrous envelope; (b) distal outer part of the tentacle; $(\mathrm{c})$ distal inner part of the tentacle; (d) proximal outer part of the tentacle; $\mathrm{cn}=$ cellular nucleus; $\mathrm{tc}=$ tentacle cilia; $\mathrm{em}=$ extracellular matrix. Arrows indicate agglomerates of heterochromatin. Scale bars: (a) $4 \mu \mathrm{m}$, (b, c) $2 \mu \mathrm{m}$, (d) $3 \mu \mathrm{m}$

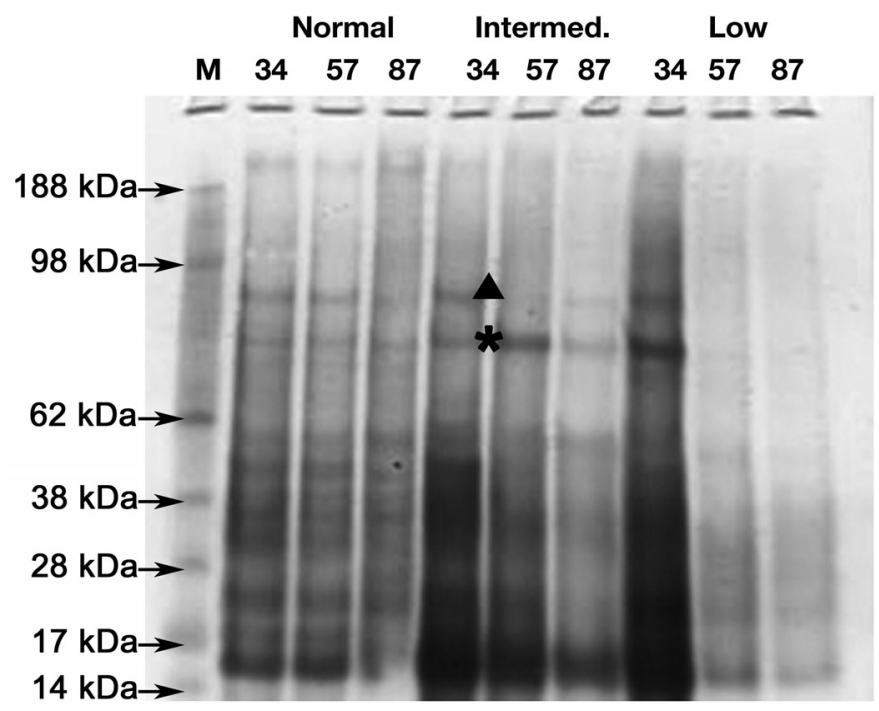

reported that $M$. truncata colonies exposed to low $\mathrm{pH}$ conditions for $45 \mathrm{~d}$, at a normal seasonal temperature, survived with a subsequent decrease in skeletal weight and a corrosion of several skeletal structures at the growing tips. The dissolution of these growing tips, which are rich in Mg-calcite, confirms the species' vulnerability to low pH even after short exposure times (Lombardi et al. 2011b). In contrast, under intermediate $\mathrm{pH}$ conditions, $M$. truncata survived

Fig. 7. Silver stained SDS PAGE gel of Myriapora truncata fragments: complex mixture of proteins from 15 to $100 \mathrm{kDa}$. Molecular weight marker (M), samples exposed to normal, intermediate and low $\mathrm{pH}$ conditions for 34,57 and $87 \mathrm{~d}$ periods starting 7 June 2009. The 76 and $95 \mathrm{kDa}$ proteins are marked by an asterisk and a triangle, respectively; for details, see 'Results' 
with an increase in skeletal weight (Rodolfo-Metalpa et al. 2010), suggesting that the species may be resilient at least after short exposure to the effects of a moderate decrease in oceanic $\mathrm{pH}$. This increase in skeletal weight could be due to the ability of the species to bud and/or to alter its skeletal structures (i.e. hypercalcification) in intermediate $\mathrm{pH}$ with normal temperature conditions.

In our study, colonies of Myriapora truncata transplanted into normal $\mathrm{pH}$ conditions continued to grow, adding up to $3.1 \pm 0.8$ new zooids per colony in $87 \mathrm{~d}$. Unfortunately, no information on the zooid growth rate of $M$. truncata is currently available in the literature. Gristina \& Balduzzi (1999) estimated a rough linear branch extension rate of $0.41 \mathrm{~cm} \mathrm{yr}^{-1}$ in the field at $4 \mathrm{~m}$ depth, suggesting a very slow colony growth rate in this species (as in many other bryozoan species; Hermansen et al. 2001). When exposed to intermediate and low $\mathrm{pH}$ conditions, $M$. truncata ceased to grow even after only $34 \mathrm{~d}$ under normal temperature conditions. Rodolfo-Metalpa et al. (2010) reported that high temperatures halted calcification even at normal $\mathrm{pH}$ sites; thus the combined effects of high temperatures and low $\mathrm{pH}$ could be potentially responsible for inhibiting growth. However, during the present experiment, colonies budded new zooids at any time at the normal $\mathrm{pH}$ site even when they were experiencing relatively high temperatures (57 and $87 \mathrm{~d}$ ), so that temperature did not affect colony growth.

The increase in skeletal weight after a short exposure described by Rodolfo-Metalpa et al. (2010) is not due to new budding but could perhaps reflect hypercalification of existing skeletal structures. Comparing colonies grown in normal versus low $\mathrm{pH}$ conditions, Lombardi et al. (2011b) reported a significant increase in the thickness of the frontal wall skeleton in distal branches, which are rich in Mg-calcite and thus more vulnerable to low $\mathrm{pH}$. These authors also reported differences when comparing distal versus proximal branches of colonies grown in both normal and low pH conditions, attributable to secondary calcification processes (i.e. thickening of skeletal structures) which commonly affect the older, proximal branches of bryozoan colonies from normal environments (McKinney \& Jackson 1989, Hayward \& Ryland 1999). This distal versus proximal difference was larger in samples from acidic sites (Lombardi et al. 2011b). Extra thickening of old colonies from low $\mathrm{pH}$ sites could represent a reaction of Myriapora truncata at the level of the biomineralisation process seen in the production of organic and, as a consequence, inorganic components.
Modifications of biomineralisation patterns, very clear in the inorganic skeleton of Myriapora truncata when subjected to low pH conditions (Rodolfo-Metalpa et al. 2010, Lombardi et al. 2011b), start at molecular and organic levels where macromolecules control skeleton formation (Fu et al. 2005, Nudelman et al. 2007, Cusack \& Freer 2008, Evans 2008). Bryozoans have an outer organic cuticle beneath which the mineralised skeleton is formed (Lutaud 1961, Tavener-Smith \& Williams 1972). In M. truncata after $34 \mathrm{~d}$, this cuticle increased in thickness at intermediate and low $\mathrm{pH}$ conditions compared to colonies from a normal $\mathrm{pH}$ environment, suggesting a protective role against dissolution of the high $\mathrm{Mg}$ calcite skeleton of colony growing tips. Samples exposed to intermediate $\mathrm{pH}$ displayed a progressive decrease in cuticle thickness from 34 to $87 \mathrm{~d}$, whereas at the low $\mathrm{pH}$ site there was a substantial decrease in cuticle thickness from 34 to $57 \mathrm{~d}$, and thereafter the values remained almost constant. The increase in cuticle thickness at the low $\mathrm{pH}$ site is accompanied by a change in appearance, with better defined, thicker and more regularly oriented fibres than at the normal $\mathrm{pH}$ site.

Ultrathin sections of tentacles from zooids at the colony growing tips of Myriapora truncata exposed to low $\mathrm{pH}$ conditions for $34 \mathrm{~d}$ revealed cells with heterochromatin-rich nuclei especially associated with the nuclear envelope. Abundance of heterochromatin may imply reduced nuclear and cell activity induced by stress factors, such as anomalous temperature as suggested by Wheatley (1985). As colonies from the normal site experienced the same temperature regime as colonies from the intermediate and low $\mathrm{pH}$ sites but did not show any trace of heterochromatin within their nuclei, modifications of nuclear and cell activities observed in samples exposed to intermediate and low pH conditions, after long (87 d) and short (34 d) periods, respectively, could have been caused by low $\mathrm{pH}$. A reduction of lophophore cellular functioning (heterochromatin associated with the nuclear margin), which also affects ciliate epithelial cells with a potential sensory function located at the tip of the tentacles (Lutaud 1993), is an expression of altered feeding activity within the colony. Because of the contrasting reaction of the cuticle and polypides to low $\mathrm{pH}$ conditions (i.e. increase in cuticle thickness versus decrease in functioning of mechanic and sensory cells over $34 \mathrm{~d}$ at least at low $\mathrm{pH}$ ), a reallocation of metabolic resources could be hypothesised for $M$. truncata. As previously observed in another Mediterranean bryozoan transplanted to decreased $\mathrm{pH}$ conditions (Lombardi et al. 
2011a), M. truncata could reallocate its energy from functions such as feeding to cuticle formation in order to slow down dissolution of the mineralised skeleton.

Changes in the band densities of proteins appear to mirror the physical changes seen in the cuticle. The amount of protein in the samples was found to reduce both with time of exposure and decrease in $\mathrm{pH}$. The most marked result was from the samples grown under low $\mathrm{pH}$ conditions, where, after $34 \mathrm{~d}$ exposure, specimens showed little protein response and a corresponding decrease in protein band intensity, only very faint bands being apparent even using the highly sensitive silver staining. In addition, very few protein bands above $45 \mathrm{kDa}$ were observed. Samples taken from the intermediate $\mathrm{pH}$ site showed a similar, though less marked effect. There appeared to be an up-regulation of protein upon initial exposure, but at $57 \mathrm{~d}$ of exposure, protein production declined, especially of the $\sim 75 \mathrm{kDa}$ band. However, unlike under low $\mathrm{pH}$ conditions, there was still a moderate amount of protein expression even after $87 \mathrm{~d}$ of exposure.

A comparison of samples exposed to normal, intermediate and low $\mathrm{pH}$ conditions, at the initial time interval of $34 \mathrm{~d}$, showed apparently stronger protein intensities in the intermediate and low $\mathrm{pH}$ environments than in the normal $\mathrm{pH}$ sample. This initial upregulation of protein is coincident with changes seen in the cuticle during this time period. While protein concentration was constant in normal conditions, colonies from both intermediate and low $\mathrm{pH}$ sites declined in protein expression at 57 and $87 \mathrm{~d}$. The decline was more marked at the low $\mathrm{pH}$ site. Since there has been little or no characterisation of bryozoan proteins to date, assigning specific protein identities to the bands observed in the above experiments was not possible. While some of the bands may be generic to a number of biomineralising proteins found in other species, there was insufficient protein to allow positive identification even using sensitive Orbitrap mass spectrometry. Although these results are preliminary, the protein analyses, along with the physical changes, suggest that Myriapora truncata may initially attempt to overcome the decrease in $\mathrm{pH}$ by up-regulating protein production (perhaps as a response to hypercalcification) but eventually, especially in the lowest $\mathrm{pH}$ condition, appears to exhaust the biochemical energy needed to maintain this rate of hypercalcification. It appears that the organism responses to combat the effects of ocean acidification may be dependent on intrinsic and extrinsic factors such as metabolism or gene/protein expression and vary with life stages (e.g. developmental stages) and body size or age and, in addition, will be highly influenced by environmental conditions (Wood et al. 2008, Gooding et al. 2009, Dupont et al. 2010). Further studies are warranted to gain information about which specific metabolic pathways are being influenced by significant decreases in $\mathrm{pH}$.

This study highlights that biogenic minerals since they are made up of organic and inorganic components - should be considered when assessing the vulnerability of organisms and their ability to respond to ocean acidification. Little is known about biomineralisation in bryozoans despite their important role in the carbon cycle and as major carbonate producers (McKinney \& Jackson 1989, Taylor \& Allison 1998). Further studies should be undertaken to increase knowledge of biomineralisation processes in bryozoans, which will help predict the effects of climatic changes such as global warming and ocean acidification on these processes.

Acknowledgements. We thank T. Wighton for sample preparation, A. Kearsley for assistance in analytical investigation, V. Zupo for use of microscopy facilities, M.C. Buia and the staff of the benthic ecology group of the Stazione Zoologica Anton Dohrn, Naples (Villa Dohrn, Ischia), for field and laboratory support. This project was financed by the Fondazione Banca del Monte di Lombardia ('Ivano Becchi' grant to C.L.) and the VECTOR project.

\section{LITERATURE CITED}

Bernhard W (1969) A new staining procedure for electron microscopical cytology. J Ultrastruct Res 27:250-265

Berning B (2007) The Mediterranean bryozoan Myriapora truncata (Pallas, 1766): a potential indicator of (palaeo-) environmental conditions. Lethaia 40:221-232

> Caldeira K, Wickett ME (2005) Ocean model predictions of chemistry changes from carbon dioxide emissions to the atmosphere and ocean. J Geophys Res 110:C09S04, doi: 10.1029/2004JC002671

Canu F, Bassler RF (1925) Les bryozoaires du Maroc et de Mauritanie. Mém Soc Sci Nat Maroc 18:1-85

Cigliano M, Gambi MC, Rodolfo-Metalpa R, Patti FP, HallSpencer JM (2010) Effects of ocean acidification on invertebrate settlement at natural volcanic $\mathrm{CO}_{2}$ vents. Mar Biol 157:2489-2502

Cocito S (2004) Bioconstruction and biodiversity: their mutual influence. Sci Mar 68:137-144

> Cölfen H, Antonietti M (2005) Mesocrystals: inorganic superstructures made by highly parallel crystallization and controlled alignment. Angew Chem Int Ed Engl 44: 5576-5591

Cusack M, Freer A (2008) Biomineralisation: elemental and organic influence in carbonate systems. Chem Rev 108: 4433-4454

Dupont S, Ortega-Martínez O, Thorndyke M (2010) Impact of near-future ocean acidification on echinoderms. Ecotoxicology 19:449-462

Evans JS (2008) 'Tuning in' to mollusc shell nacre- and 
prismatic-associated protein terminal sequences. Implications for biomineralization and the construction of high performance inorganic-organic composites. Chem Rev 108:4455-4462

> Ferretti C, Magnino G, Balduzzi A (2007) Morphology of the larva and ancestrula of Myriapora truncata (Bryozoa, Cheilostomatida). Ital J Zool 74:341-350

Fu G, Valiyaveettil S, Wopenka B, Morese DE (2005) $\mathrm{CaCO}_{3}$ biomineralization: acidic 8-kDa proteins isolated from aragonite abalone shell nacre can specifically modify calcite crystal morphology. Biomacromolecules 6: 1289-1298

Gattuso JP, Allemand D, Frankignulle M (1999) Photosynthesis and calcification at cellular, organismal and community levels in coral reefs: a review on interactions and control by carbonate chemistry. Am Zool 36:160-183

> Gieskes JM (1969) Effects of temperature on the $\mathrm{pH}$ of seawater. Limnol Oceanogr 14:679-685

Gooding RA, Harley CDG, Tang E (2009) Elevated water temperature and carbon dioxide concentration increase the growth of a keystone echinoderm. Proc Natl Acad Sci USA 106:9316-9321

- Gordon DP (1971) Zooidal budding in the cheilostomatous bryozoan Fenestrulina mausii var. thyreophora. NZ J Mar Freshw Res 5:453-460

Gordon DP (1974) Microarchitecture and function of the lophophore in the bryozoan Cryptosula pallasiana. Mar Biol 27:147-163

Gristina M, Balduzzi A (1999) Preliminary data on the growth of Myriapora truncata in Ustica Island (N/W Sicily) (Bryozoa: Cheilostomatida). Biol Mar Mediterr 6: 256-258

> Hageman S, Needham L, Todd C (2009) Threshold effects of food concentration on the skeletal morphology of the bryozoan Electra pilosa (Linnaeus, 1767). Lethaia 42: $438-451$

Hall-Spencer JM, Rodolfo-Metalpa R, Martin S, Ransome E and others (2008) Volcanic carbon dioxide vents show ecosystem effects of ocean acidification. Nature 454: 96-99

Hayward PJ, Ryland JS (1999) Cheilostomatous Bryozoa. Part 2: Hippothooidea - Celleporoidea. In: Barnes RSK, Crothers JH (eds) Linnean synopses of the British fauna (new series). Field Studies Council, Shrewsbury, p 207-221

> Hermansen P, Larsen PS, Riisgard HU (2001) Colony growth rate of encrusting marine bryozoans (Electra pilosa and Celleporella hyalina). J Exp Mar Biol Ecol 263:1-23

Hunt S (1972) Scleroprotein and chitin in the exoskeleton of the ectoproct Flustra foliacea. Comp Biochem Physiol 43: $571-577$

Jackson JBC, Herrera Cubilla A (2000) Adaptation and constraint as determinants of zooid and ovicell size among encrusting ascophoran cheilostome Bryozoa from opposite sides of the Isthmus of Panama. In: Herrera-Cubilla A, Jackson JBC (eds) Proc 11th Int Bryozool Assoc Conf, Smithsonian Tropical Res Inst, Panama, p 249-258

Kleypas JA, Feely RA, Fabry VJ, Langdon C, Sabine CL, Robbins LL (2006) Impact of ocean acidification on coral reefs and other marine calcifiers: a guide for future research. US Geological Survey, St. Petersburg, FL

Knowles T, Leng MJ, Williams M, Taylor PD, Sloane HJ, Okamura B (2010) Interpreting seawater temperature range using oxygen isotopes and zooid size variation in Pentapora foliacea (Bryozoa). Mar Biol 157:1171-1180
Kohler KE, Gill SM (2006) Coral Point Count with Excel extensions (CPCe): a Visual Basic program for the determination of coral and substrate coverage using random point count methodology. Comput Geosci 32:1259-1269

Lombardi C, Cocito S, Occhipinti-Ambrogi A, Hiscock K (2006) The influence of seawater temperature on zooid size and growth rate in Pentapora fascialis (Bryozoa: Cheilostomata). Mar Biol 149:1103-1109

Lombardi C, Cocito S, Hiscock K, Occhipinti-Ambrogi A, Setti M, Taylor PD (2008) Influence of seawater temperature on growth bands, mineralogy and carbonate production in a bioconstructional bryozoan. Facies 54: 333-342

Lombardi C, Gambi MC, Vasapollo C, Taylor PD, Cocito S (2011a) Skeletal alterations and polymorphism in a Mediterranean bryozoan at natural $\mathrm{CO}_{2}$ vents. Zoomorphology 130:135-145

> Lombardi C, Rodolfo-Metalpa R, Cocito S, Gambi MC, Taylor PD (2011b) Structural and geochemical alterations in the Mg calcite bryozoan Myriapora truncata under elevated seawater $p \mathrm{CO}_{2}$ simulating ocean acidification. PSZN I: Mar Ecol 32:211-222

López de la Cuadra CM, García-Gómez JC (1994) Zoogeographical study of the Cheilostomatida of the Strait of Gibraltar. In: Hayward PJ, Ryland JS, Taylor PD (eds) Biology and palaeobiology of bryozoans. Olsen \& Olsen, Fredensburg, p 107-112

Lutaud G (1961) Contribution a l'étude du bourgeonnement et la croissance des colonies chez Membranipora membranacea (Linné) bryozoaire cheilostome. Ann Soc R Zool Belg 91:157-300

Lutaud G (1973) L'innervation du lophophore chez le bryozoaire chielostome Electra pilosa (L.). Z Zellforsch 140: $217-234$

Lutaud G (1993) L'innervation sensorielle du lophophore et de la région orale chez les bryozoaires chielostomes. Ann Sci Nat Zool 13:137-146

> Marin F, Smith M, Isa Y, Muyzer G, Westbroek P (1996) Skeletal matrices, muci, and the origin of invertebrate calcification. Proc Natl Acad Sci USA 93:1554-1559

McKinney FK, Jackson JBC (1989) Bryozoan evolution. The University of Chicago Press, Chicago, IL

> Noguchi T, Torita A, Hasegawa Y (2007) Purification and characterization of a matrix shell protein from the shell of scallop Patinopecten yessoensis. Fish Sci 73: 1177-1185

Nudelman F, Chen HH, Goldberg HA, Weiner S, Lia Addadi L (2007) Lessons from biomineralization: comparing the growth strategies of mollusc shell prismatic and nacreous layers in Atrina rigida. Faraday Discuss 136:9-25

> O'Dea A, Okamura B (1999) Influence of seasonal variation in temperature, salinity and food availability on module size and colony growth of the estuarine bryozoan Conopeum seurati. Mar Biol 135:581-588

> Orr JC, Fabry VJ, Aumont O, Bopp L and others (2005) Anthropogenic ocean acidification over the twenty-first century and its impacts on calcifying organisms. Nature 437:681-686

Perrin C (2003) Compositional heterogeneity and microstructural diversity of the coral skeletons: implications for taxonomy and control on early diagenesis. Coral Reefs 22:109-120

Pörtner HO, Langenbuch M, Michaelidis B (2005) Synergistic effects of temperature extremes, hypoxia, and increases in $\mathrm{CO}_{2}$ on marine animals: from Earth history to 
global change. J Geophys Res 110:C09S10, doi:10.1029/ 2004JC002561

Raven J, Caldeira K, Elderfield H, Hoegh-Guldberg O and others (2005) Ocean acidification due to increasing atmospheric carbon dioxide. Policy Document 12/05. The Royal Society, London

Ries J, Cohen A, McCorkle D (2009) Marine calcifiers exhibit mixed responses to $\mathrm{CO}_{2}$-induced ocean acidification. Geology 37:1131-1134

Rodolfo-Metalpa R, Lombardi C, Cocito S, Hall-Spencer J, Gambi MC (2010) Effects of acidification and high temperature on the bryozoan Myriapora truncata at natural $\mathrm{CO}_{2}$ vents. PSZN I: Mar Ecol 31:447-456

Roer R, Dillaman R (1984) The structure and calcification of the crustacean cuticle. Am Zool 24:893-909

Smith AM (2009) Bryozoans as southern sentinels of ocean acidification: a major role for a minor phylum. Mar

Editorial responsibility: Riccardo Cattaneo-Vietti,

Genova, Italy
Freshw Res 60:475-482

Switzer RC III, Merril CR, Shifrin S (1979) A highly sensitive silver stain for detecting proteins and peptides in polyacrylamide gels. Anal Biochem 98:231-237

Tavener-Smith R, Williams A (1972) The secretion and structure of the skeleton of living and fossil Bryozoa. Philos Trans R Soc Lond B Biol Sci 264:97-160

Taylor PD, Allison PA (1998) Bryozoan carbonates through time and space. Geology 26:459-462

Wheatley DN (1985) Investigation of the mechanism of protein turnover in HeLa S-3 cells by incubation at elevated temperature. Exp Cell Res 157:159-171

Winston JE (1978) Polypide morphology and feeding behavior in marine ectoprocts. Bull Mar Sci 28:1-31

> Wood HL, Spicer JI, Widdicombe S (2008) Ocean acidification may increase calcification rates, but at a cost. Proc Biol Sci 275:1767-1773

Submitted: May 30, 2011; Accepted: September 3, 2011 Proofs received from author(s): October 19, 2011 